\title{
Viral RNA-Dependent RNA Polymerase Inhibitor 7-Deaza-2'-C- Methyladenosine Prevents Death in a Mouse Model of West Nile Virus Infection
}

\author{
Luděk Eyer,a,b Martina Fojtíková, ${ }^{a}$ Radim Nencka,c Ivo Rudolf, d,e Zdeněk Hubálek, d,e (1) Daniel Ruzekª,b \\ aDepartment of Virology, Veterinary Research Institute, Brno, Czech Republic \\ bInstitute of Parasitology, Biology Centre of the Czech Academy of Sciences, Ceske Budejovice, Czech Republic \\ Institute of Organic Chemistry and Biochemistry, The Czech Academy of Sciences, Prague, Czech Republic \\ dThe Czech Academy of Sciences, Institute of Vertebrate Biology, Brno, Czech Republic \\ eMasaryk University, Department of Experimental Biology, Brno, Czech Republic
}

\begin{abstract}
West Nile virus (WNV) is a medically important emerging arbovirus causing serious neuroinfections in humans and against which no approved antiviral therapy is currently available. In this study, we demonstrate that 2'-C-methyl- or 4 '-azido-modified nucleosides are highly effective inhibitors of WNV replication, showing nanomolar or low micromolar anti-WNV activity and negligible cytotoxicity in cell culture. One representative of $C 2^{\prime}$-methylated nucleosides, 7-deaza-2'-Cmethyladenosine, significantly protected WNV-infected mice from disease progression and mortality. Twice daily treatment at $25 \mathrm{mg} / \mathrm{kg}$ starting at the time of infection resulted in $100 \%$ survival of the mice. This compound was highly effective, even if the treatment was initiated 3 days postinfection, at the time of a peak of viremia, which resulted in a $90 \%$ survival rate. However, the antiviral effect of 7-deaza- 2 '-Cmethyladenosine was absent or negligible when the treatment was started 8 days postinfection (i.e., at the time of extensive brain infection). The 4 '-azido moiety appears to be another important determinant for highly efficient inhibition of WNV replication in vitro. However, the strong anti-WNV effect of 4 '-azidocytidine and 4' azido-aracytidine was cell type dependent and observed predominantly in porcine kidney stable (PS) cells. The effect was much less pronounced in Vero cells. Our results indicate that 2'-C-methylated or 4'-azidated nucleosides merit further investigation as potential therapeutic agents for treating WNV infections as well as infections caused by other medically important flaviviruses.
\end{abstract}

KEYWORDS West Nile virus, antiviral agents, flavivirus, nucleoside analogs

W lest Nile virus (WNV) is an emerging representative of the genus Flavivirus belonging to the family Flaviviridae. This family also includes other medically important human pathogens, such as dengue virus (DENV), Japanese encephalitis virus (JEV), yellow fever virus (YFV), Zika virus (ZIKV), and tick-borne encephalitis virus (TBEV) (1). WNV has been serologically classified into the JEV antigenic complex and divided into eight genotypic lineages; from a medical point of view, the strains pathogenic for humans are designated as lineages 1 and 2 (2). WNV virions (50 nm diameter) are enveloped with a host cell-derived lipid bilayer containing single-stranded, plus-sense genomic RNA $11 \mathrm{~kb}$ in length. The WNV genome encodes a single polyprotein processed into three structural (capsid, premembrane or membrane, and envelope) and seven nonstructural (NS1, NS2A, NS2B, NS3, NS4A, NS4B, and NS5) proteins (3-6). NS5 shows RNA-dependent RNA polymerase (RdRp) activity and has been reported to be an important target for antiviral development (4).
Citation Eyer L, Fojtíková M, Nencka R, Rudolf I, Hubálek Z, Ruzek D. 2019. Viral RNA-dependent RNA polymerase inhibitor 7-deaza-2'-Cmethyladenosine prevents death in a mouse model of West Nile virus infection. Antimicrob Agents Chemother 63:e02093-18. https://doi .org/10.1128/AAC.02093-18.

Copyright $\odot 2019$ American Society for Microbiology. All Rights Reserved.

Address correspondence to Daniel Ruzek, ruzekd@paru.cas.cz.

L.E. and M.F. contributed equally to this work. Received 1 October 2018 Returned for modification 6 November 2018 Accepted 4 January 2019

Accepted manuscript posted online 14 January 2019

Published 26 February 2019 
WNV circulates in nature within an enzootic transmission cycle between birds as reservoir hosts and bird-feeding mosquitoes, primarily involving Culex spp. as principal vectors of WNV (7). WNV was originally isolated in Africa in 1937 (8) and later caused outbreaks in Europe, the Middle East, and parts of Asia and Australia (9). Following its introduction into the United States in 1999, WNV rapidly disseminated across North America and has further spread to Mexico, South America, and the Caribbean $(10,11)$. In humans, WNV infection often remains subclinical $(12,13)$, but $20 \%$ to $40 \%$ of those infected may develop WNV disease, which manifests as a febrile illness that can progress to lethal encephalitis. Symptoms include cognitive dysfunction and acute flaccid paralysis (14-16). Overall, 2,002 cases of WNV disease in humans were reported in the United States in $2017,67 \%$ of which were classified as neuroinvasive disease (e.g., meningitis or encephalitis) and $33 \%$ as nonneuroinvasive infection (https://www.cdc .gov/westnile). As no vaccines or specific therapies for WNV are currently approved for humans, there is an urgent need for an effective approach to treatment based on specific inhibitors of WNV replication (17).

Nucleoside analogs represent an important group of small molecule-based inhibitors that have figured prominently in the search for effective antiviral agents (18). After they enter the cell, nucleoside analogs are phosphorylated by cellular kinases and incorporated into viral nascent RNA chains $(19,20)$. As the 3' hydroxyl of nucleoside inhibitors is conformationally constrained or sterically/electronically hindered (nonobligate chain terminators) or completely missing (obligate chain terminators), such structures exert a decreased potency to form a phosphodiester linkage with the incoming nucleoside triphosphate during viral RNA replication, resulting in the premature termination of viral nucleic acid synthesis (21). Currently, there are more than 25 approved therapeutic nucleosides used for the treatment of viral infections of high medical importance, such as HIV/AIDS, hepatitis B, hepatitis C, and herpes infections (22-26). Therefore, nucleoside analogs represent promising tools that can be repurposed against mosquito-transmitted flaviviruses, including WNV.

The aim of this study was to assess anti-WNV activity and cytotoxicity in a series of methyl- or azido-substituted nucleosides. We have demonstrated that the $2^{\prime}$-C-methyl or $4^{\prime}$-azido substituents are crucial structural elements for highly efficient WNV inhibition and low cytotoxicity in cell culture. One representative of 2 '-methylated nucleosides, 7-deaza-2'-C-methyladenosine (7-deaza-2'-CMA), significantly protected WNVinfected mice from disease progression and mortality, even if the treatment was started 3 days postinfection (p.i.). Thus, $2^{\prime}$ - $C$-methylated or $4^{\prime}$-azidated nucleosides merit further investigation as therapeutic agents for treating WNV infections and, hypothetically, infections caused by other medically important flaviviruses.

\section{RESULTS}

In vitro antiviral effect and cytotoxicity of the tested compounds. Nucleosides with a methyl substituent at the $C 2$ ' position exhibited nanomolar or low-micromolar dose-dependent anti-WNV activity when tested on either porcine kidney stable (PS) or Vero cell cultures (Table 1, Fig. 1A and B and 2A and B). 7-Deaza-2'-CMA, also denoted as MK-0608, exerted the strongest antiviral effect of all 2'-C-methylated nucleosides tested, characterized by $50 \%$ effective concentration $\left(\mathrm{EC}_{50}\right)$ values of $0.33 \pm 0.08 \mu \mathrm{M}$ and $0.15 \pm 0.05 \mu \mathrm{M}$ for Eg-101 and 13-104, respectively. The anti-WNV effect of 7-deaza-2'-CMA was confirmed also in human neuroblastoma cell line SK-N-SH (Fig. 1D). In this case, treatment with 7-deaza-2'-CMA at a concentration of $50 \mu \mathrm{M}$ resulted in reductions of viral titers of $10^{5}$-fold (Eg-101) and 106-fold (13-104) compared to that of mock-treated cells. $\mathrm{EC}_{50}$ values for $2^{\prime}-\mathrm{C}$-methyladenosine, $2^{\prime}-\mathrm{C}$ methylguanosine, and 2'-C-methylcytidine in PS cells were slightly higher than those for 7-deaza-2'-CMA, ranging from $0.78 \pm 0.16 \mu \mathrm{M}$ to $0.96 \pm 0.06 \mu \mathrm{M}$ for Eg-101 and from $0.66 \pm 0.15 \mu \mathrm{M}$ to $1.67 \pm 0.50 \mu \mathrm{M}$ for $13-104$. Similarly to $\mathrm{BCX}-4430$, which is used as a positive control for in vitro antiviral screens, these compounds (at a concentration of $50 \mu \mathrm{M}$ ) decreased the viral titer $10^{5}$ - to $10^{6}$-fold compared to that of mock-treated cells, and the in vitro antiviral effect was stable up to 5 days p.i. (Fig. 2C). 2'-C- 
TABLE 1 WNV inhibition and cytotoxicity characteristics of the studied nucleoside analogues in PS cells

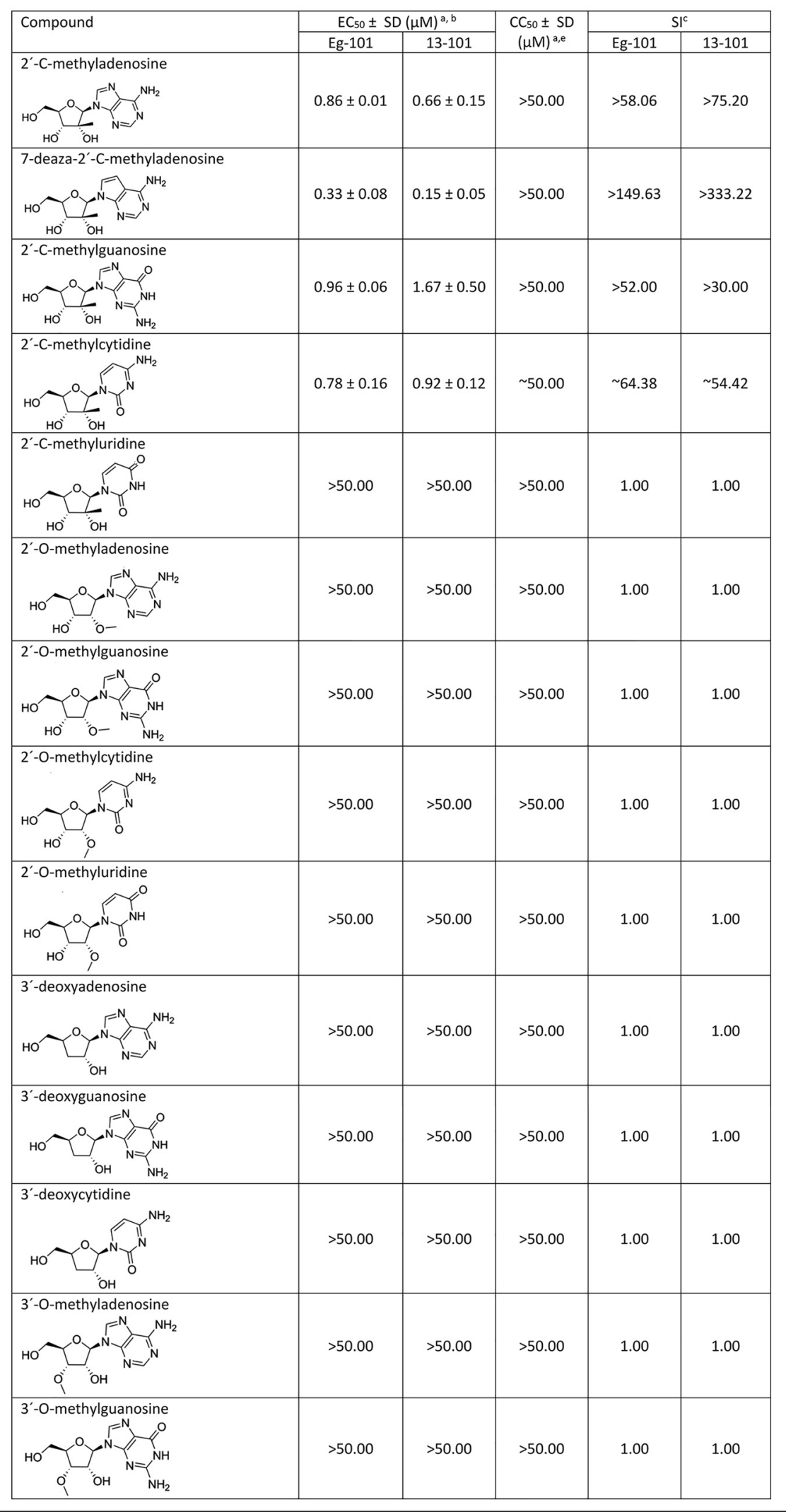

(Continued on next page) 
TABLE 1 (Continued)

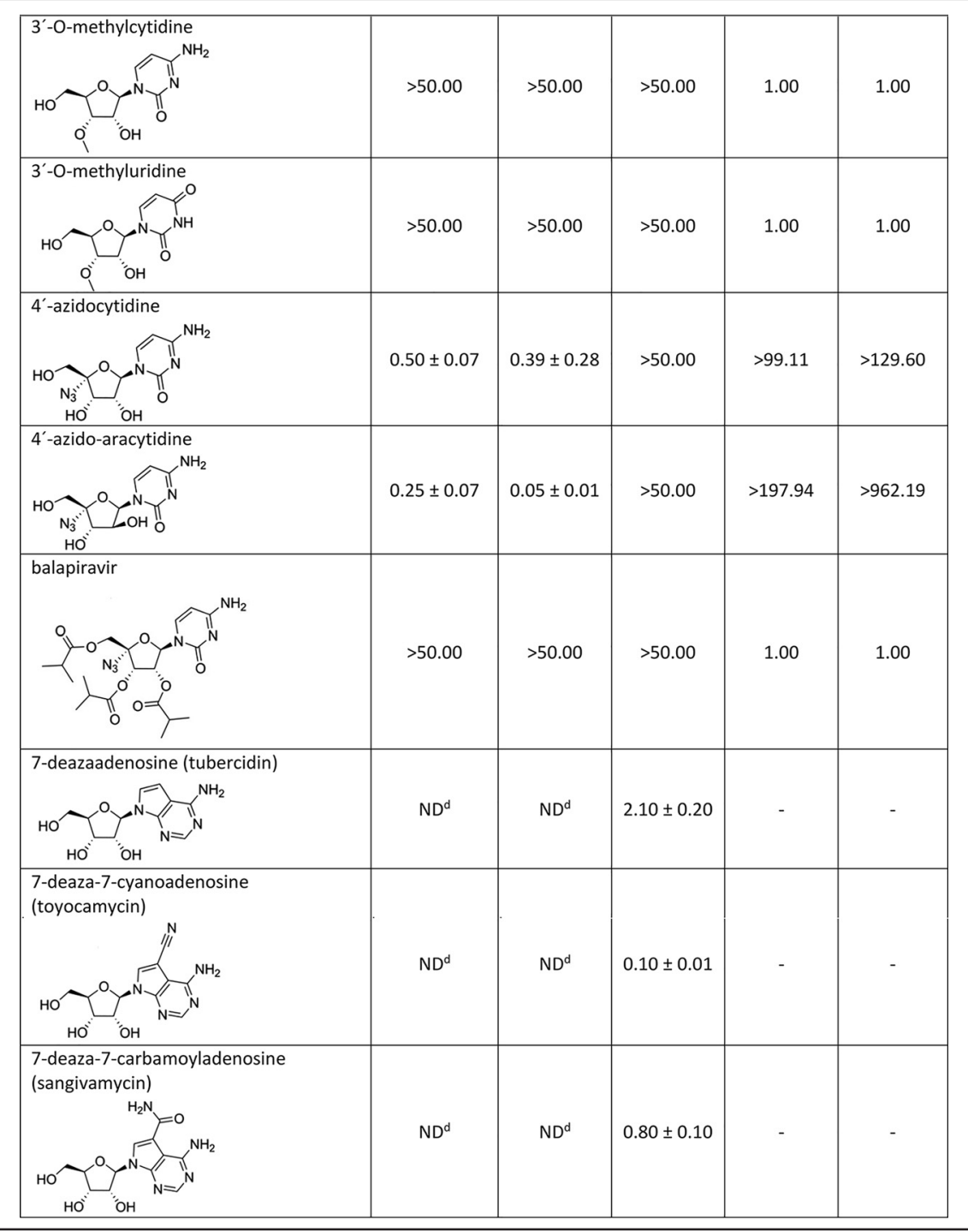

aDetermined from three independent experiments.

${ }^{b}$ Expressed as a $50 \%$ reduction of viral titers and calculated as inflection points of sigmoidal inhibitory curves, which were obtained by a nonlinear fit of transformed inhibitor concentrations versus normalized response using GraphPad Prism 7.04 (GraphPad Software, Inc., USA).

cSI $=\mathrm{CC}_{50} / \mathrm{EC}_{50}$.

${ }^{d} \mathrm{ND}$, not determined.

eValues reported previously by Eyer et al. (27).

Methyluridine was almost inactive against both WNV strains $\left(\mathrm{EC}_{50}>50 \mu \mathrm{M}\right)$ when tested on porcine kidney stable (PS) cell monolayers and exhibited only weak inhibitory activity in Vero cells (Fig. 1A and B). 2'-C-Methyl-modified nucleosides exerted low cytotoxicity in both PS and Vero cells (50\% cytotoxic concentration $\left[\mathrm{CC}_{50}\right]>50 \mu \mathrm{M}$ ) (Table 1, Fig. 1C), except $2^{\prime}-C$-methylcytidin had a $C C_{50}$ value of $\sim 50 \mu \mathrm{M}$ in PS cells 3 days posttreatment, as we reported previously (27). 7-Deaza-2'-CMA exerted no cytotoxicity also for human neuroblastoma cells (tested up to $50 \mu \mathrm{M}$ ) (data not shown).

2'-O-Methyl- or 3'-O-methyl-substituted nucleosides demonstrated no inhibitory effects on WNV replication. Similarly, 3'-deoxy nucleosides were completely inactive against WNV (Fig. 1A and B). These compounds did not cause any morphological changes and did not result in decreased PS/Vero cell viability $\left(\mathrm{CC}_{50}>50 \mu \mathrm{M}\right)$ at concentrations up to $50 \mu \mathrm{M}$ after 3 days posttreatment (Table 1). Interestingly, 7-deazaadenosine (tubercidin) and its 7-cyano- and 7-carbamoyl-substituted deriva- 
A

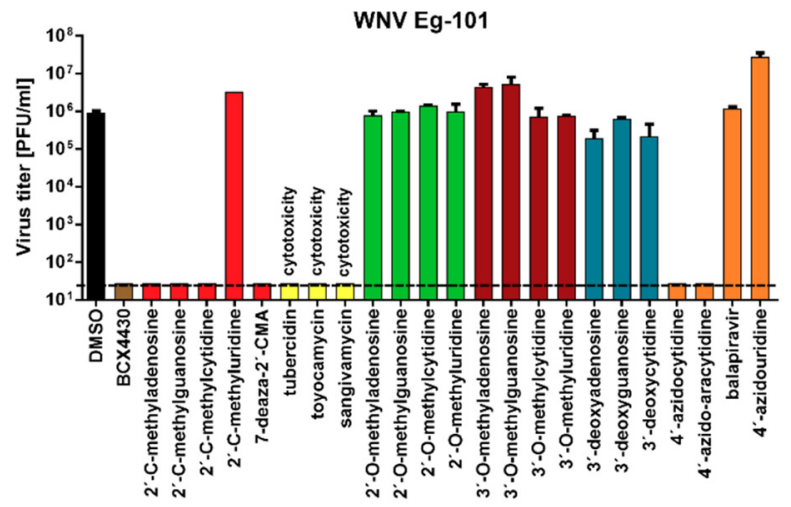

B

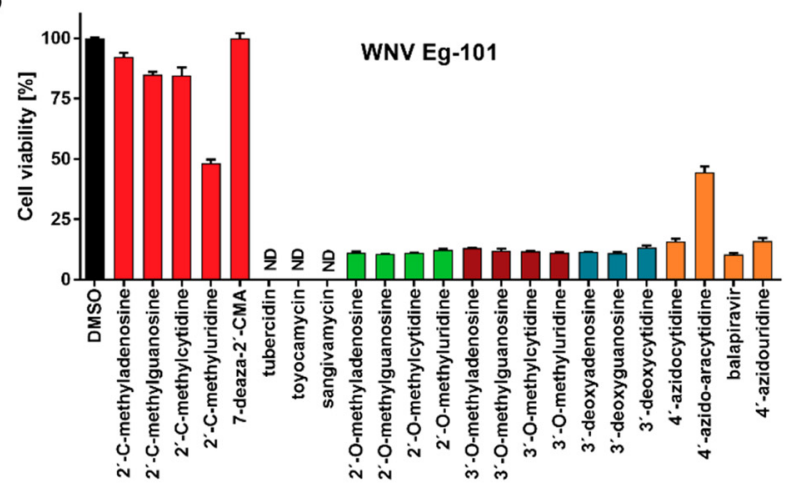

C

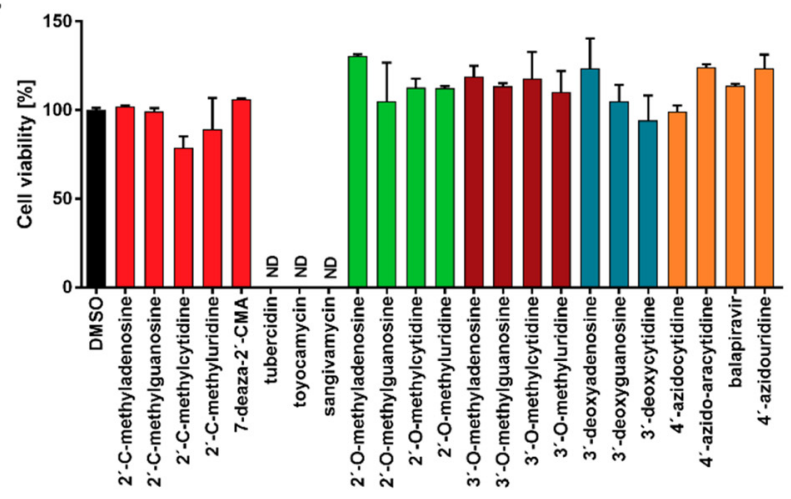

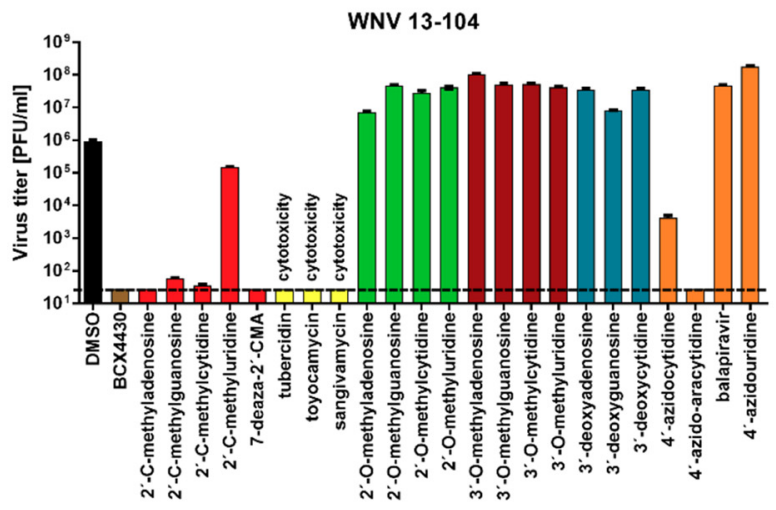

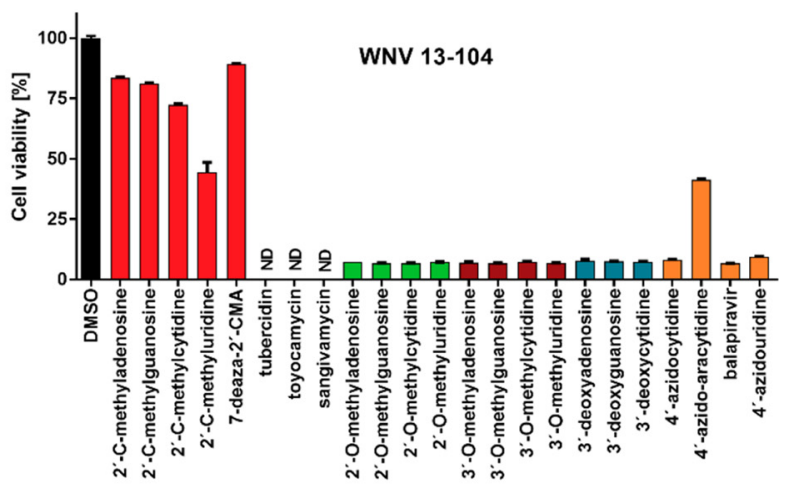

D

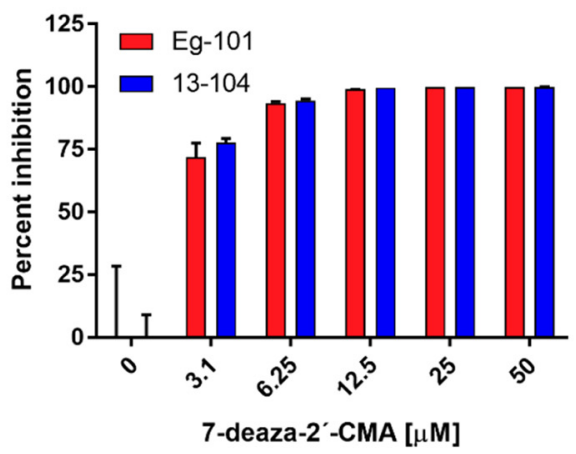

E
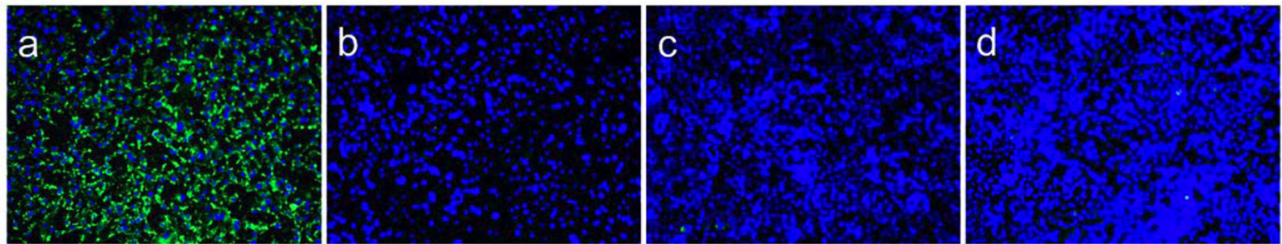

e
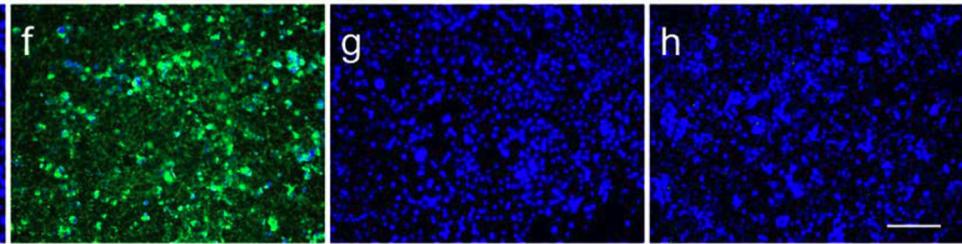

FIG 1 (A) Reduction of West Nile virus (WNV) titers by the indicated nucleoside analogs. PS cells were infected with WNV Eg-101 or 13-104 strain at a multiplicity of infection (MOI) of 0.1 and then treated with $50 \mu \mathrm{M}$ nucleoside analogs. WNV titers were determined by plaque assay 3 days (Continued on next page) 
tives (toyocamycin and sangivamycin, respectively) were highly cytotoxic at $50 \mu \mathrm{M}$; therefore, their anti-WNV profiles were excluded from further testing (Table 1, Fig. 1A to $C)$.

We evaluated four representatives of $4^{\prime}$-azido-modified nucleoside scaffolds for their potential anti-WNV and cytotoxic effects: $4^{\prime}$-azidocytidine (denoted R-1479), balapiravir (an ester prodrug of $4^{\prime}$-azidocytidine), $4^{\prime}$-azido-aracytidine (a stereoisomeric counterpart of 4'-azidocytidine, denoted RO-9187), and 4'-azidouridine. 4'-Azidocytidine completely inhibited in vitro replication of the Eg-101 strain at a concentration of $50 \mu \mathrm{M}$ $\left(\mathrm{EC}_{50}\right.$ value, $0.50 \pm 0.07 \mu \mathrm{M}$ ) in PS cells. In the case of the 13-104 strain, the inhibitory effect of $4^{\prime}$-azidocytidine was only partial, manifesting as a $10^{3}$-fold decrease in viral titer at $50 \mu \mathrm{M}$ compared to that of mock-infected PS cells. Remarkably strong anti-WNV activity was observed for 4 '-azido-aracytidine, with $\mathrm{EC}_{50}$ values of $0.25 \pm 0.07 \mu \mathrm{M}$ for Eg-101 and $0.05 \pm 0.01 \mu \mathrm{M}$ for 13-104 (Fig. 1A). The high antiviral potencies of both 4 '-azidocytidine and 4'-azido-aracytidine have been demonstrated only in PS cells; in Vero cells, the effect was significantly less pronounced (Fig. 1B). The anti-WNV effects of $4^{\prime}$-azidouridine and balapiravir were completely abrogated $\left(\mathrm{EC}_{50}>50 \mu \mathrm{M}\right)$ (Fig. $1 \mathrm{~A}$ and B). Though treating the PS cell culture with $50 \mu \mathrm{M} 4^{\prime}$-azido-aracytidine slightly reduced the cell viability (86.9\%) (27), the cytotoxicity of the other $4^{\prime}$-azido-substituted nucleosides tested in this study was absent or negligible (Table 1, Fig. 1C).

The antiviral effects of WNV inhibitors identified by viral titer/cytopathic effect (CPE) inhibition assays were confirmed by immunofluorescence staining, which was used to assess the expression of WNV surface E antigen in PS cells as an index of viral infectivity and replication in vitro. Though the surface $E$ protein was highly expressed in WNVinfected mock-treated cells (Fig. 1E), no viral antigen was detected in mock-infected cells (data not shown). Immunofluorescence staining revealed that $50 \mu \mathrm{M}$ 7-deaza-2' CMA, 2'-C-methyladenosine, 2'-C-methylguanosine, 2'-C-methylcytidine, or 4'-azidoaracytidine considerably suppressed the expression of WNV surface $E$ antigen, from both the Eg-101 and 13-104 strain, in virus-infected PS cells. As expected, WNV surface antigen was expressed extensively in cells treated with $2^{\prime}-C$-methyluridine (Fig. 1E). Slight E protein expression was also observed in cells infected with 13-104 strain treated with 4'-azidocytidine (data not shown). The results correlate with the observed inhibition of WNV replication in compound-treated cell cultures.

Antiviral efficacy of 7-deaza-2' -CMA in a mouse model of lethal WNV infection. Based on the results showing 7-deaza-2'-CMA strongly inhibited WNV replication in vitro, we used this nucleoside to demonstrate its anti-WNV effect in a mouse model of WNV infection (Fig. 3A). WNV strain Eg-101 exhibits low pathogenicity in adult mice (28); therefore, WNV strain 13-104 was used in the in vivo experiments. BALB/c mice infected subcutaneously with a lethal dose of strain 13-104 (103 PFU/mouse) exhibited characteristic clinical signs of infection, such as ruffled fur, hunched posture, tremor, and paralysis of the limbs, within days 7 to 12 days p.i., with the majority of mice requiring euthanasia (Fig. 3B and $\mathrm{C}$ ). The infection was accompanied by a rapid loss of body weight starting 7 days p.i., with a loss of more than $20 \%$ by 12 days p.i. (Fig. 3D). The mortality rate was $95 \%$ to $100 \%$ with a mean survival time of $10.5 \pm 1.9$ days (Fig. 2B). Viable virus was detected in the brains of WNV-infected mice 10 days p.i., which was characterized by a mean viral titer of $3.87 \times 10^{4} \mathrm{PFU} / \mathrm{ml}$ (Fig. 3E).

FIG 1 Legend (Continued)

postinfection. Viral titers are expressed as PFU/ml. The horizontal dashed line indicates the minimum detectable threshold of 1.44 log ${ }_{10}$ PFU/ml. (B) Inhibition of WNV-induced CPE by the indicated nucleoside analogs in Vero cells expressed as a percentage of cell viability 3 days postinfection. ND, not detected (below the detection limit). (C) The cytotoxicity of nucleoside inhibitors was determined by treatment of Vero cells with $50 \mu \mathrm{M}$ of the indicated nucleoside analogs and was expressed in terms of cell viability 3 days postinfection. ND, not detected (below the detection limit). (D) Anti-WNV effect of 7-deaza-2'-CMA in human neuroblastoma cells (SK-N-SH) within the concentration range from 0 to $50 \mu M$. Bars indicate the mean values from two independent experiments performed in three replicate wells, and the error bars indicate the standard errors of the means. (E) Inhibition of WNV viral antigen expression by nucleoside inhibitors. PS cells were infected with WNV and treated with $0.5 \%$ DMSO (a) or $50 \mu$ M 2'-C-methyladenosine (b), 7-deaza-2'-CMA (c), 2'-C-methylguanosine (d), 2'-C-methylcytidine (e), 2'-C-methyluridine (f), 4'-azidocytidine (g), or $4^{\prime}$-azido-aracytidine (h). PS cells were fixed with cold methanol-acetone 3 days postinfection and stained with a flavivirus-specific antibody labeled with FITC (green) and counterstained with DAPI (blue). Scale bars, $50 \mu \mathrm{m}$. 

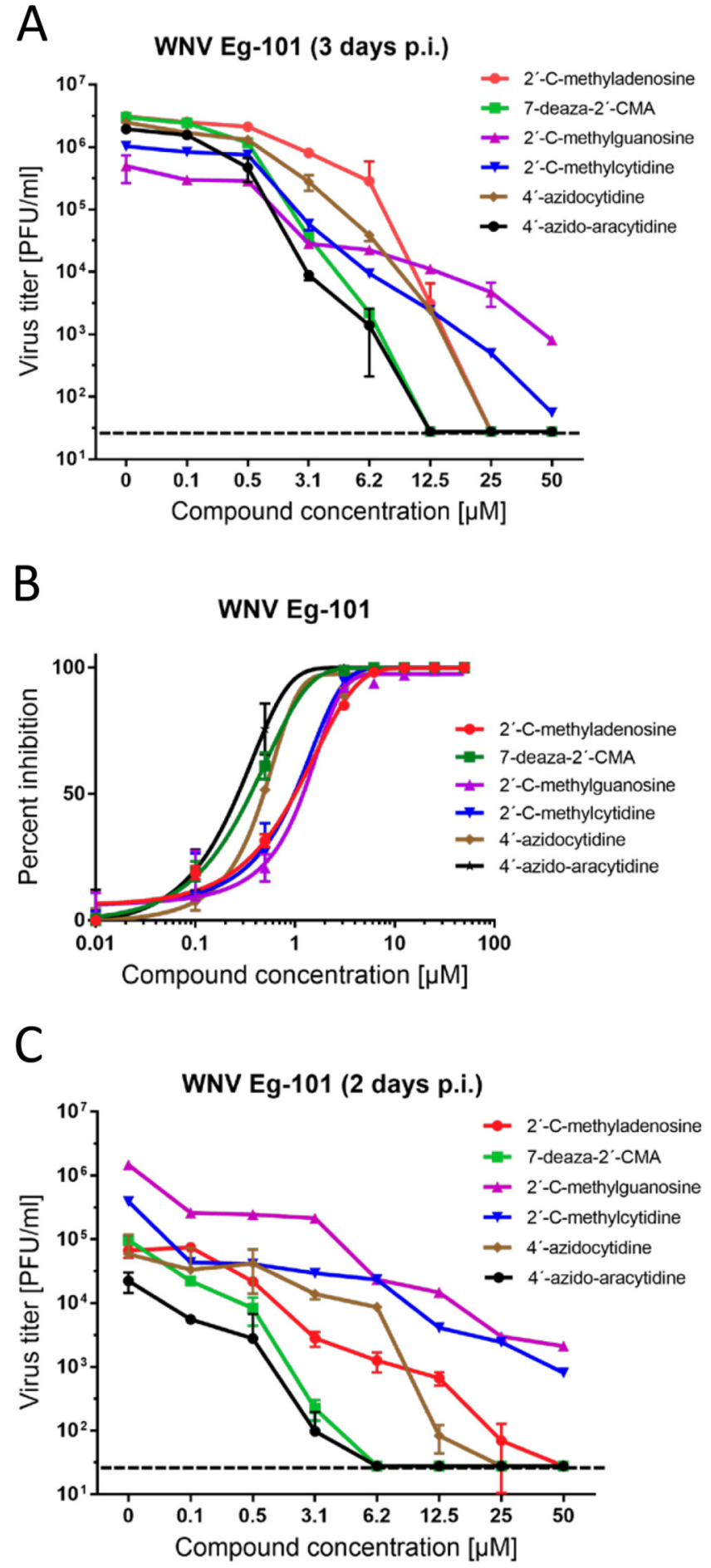

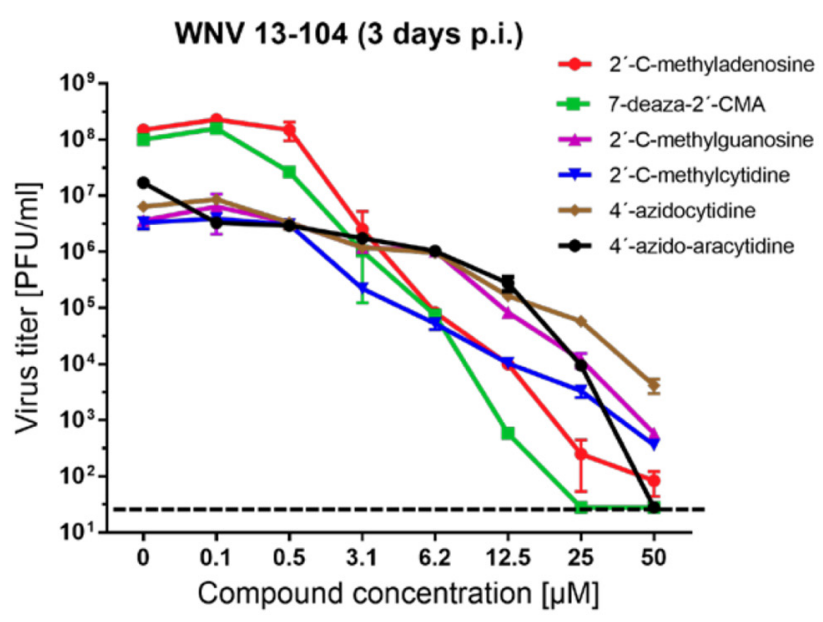

WNV 13-104
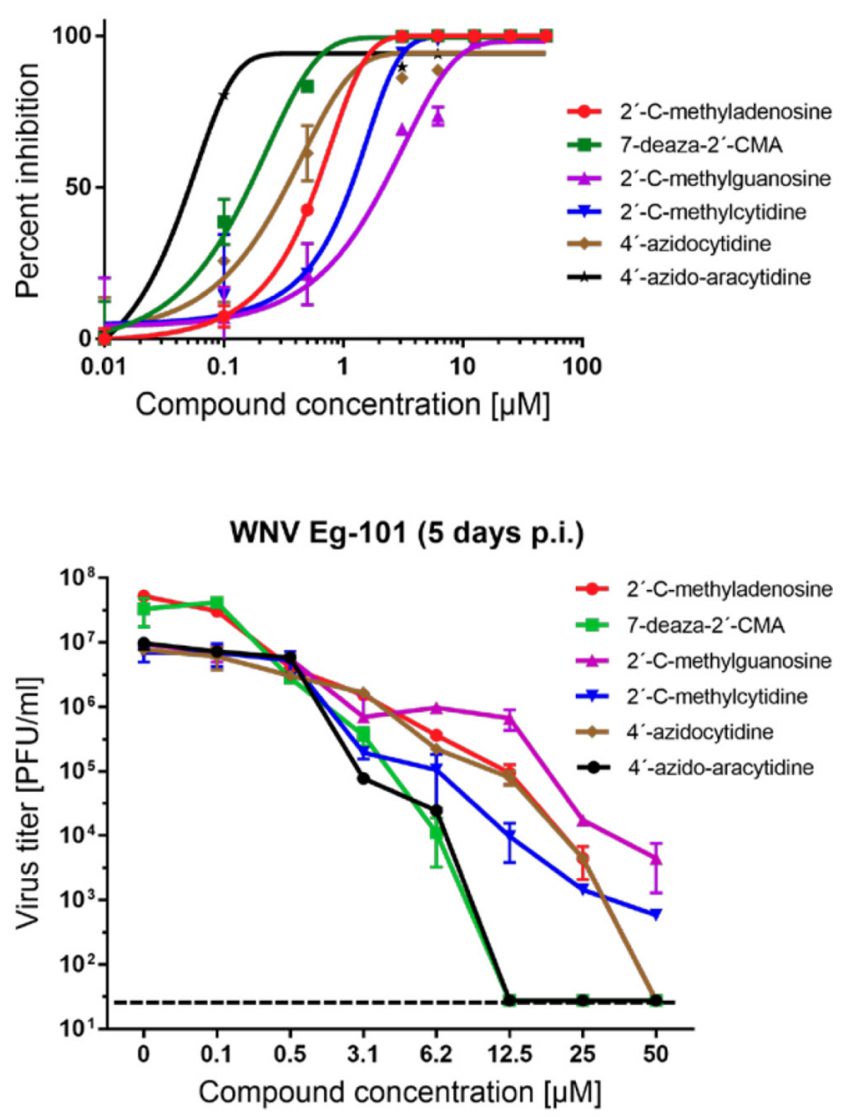

FIG 2 (A) Dose-dependent effects of the indicated West Nile virus (WNV) inhibitors on Eg-101 or 13-104 titer. PS cells were infected with WNV at a multiplicity of infection (MOI) of 0.1 and treated with the appropriate inhibitor at the indicated concentrations 3 days postinfection. The mean titers from two independent experiments performed in three biological replicates are shown, and error bars indicate standard errors of the mean. The horizontal dashed line indicates the minimum detectable threshold of $1.44 \log _{10}$ PFU/ml. (B) Sigmoidal inhibition curves for WNV strains Eg-101 and $13-104$ in the presence of a serial dilution of indicated nucleoside analogs. (C) Dose-dependent effects of the indicated WNV inhibitors on Eg-101 titer at 2 and 5 days postinfection in PS cells.

Treatment with $25 \mathrm{mg} / \mathrm{kg}$ of 7-deaza-2'-CMA twice a day, initiated at the time of virus inoculation and ceased 19 days p.i., resulted in a $100 \%$ survival rate $(P<0.0001)$ among WNV-infected mice (Fig. 3B). Nine of ten animals exhibited no clinical signs during the entire 28-day monitoring period; in one mouse, we observed slightly bristled 


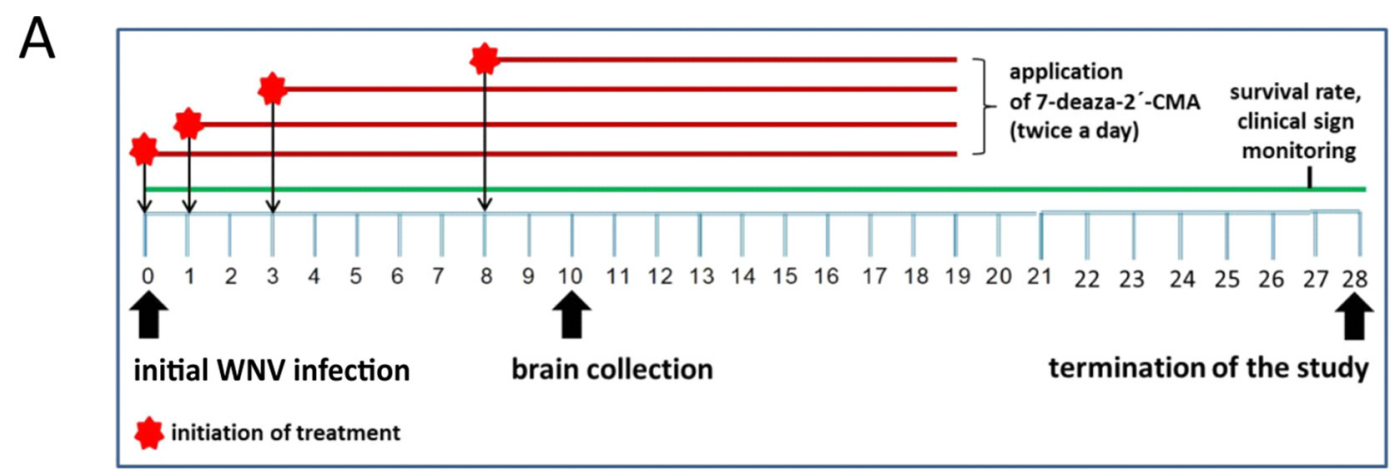

B
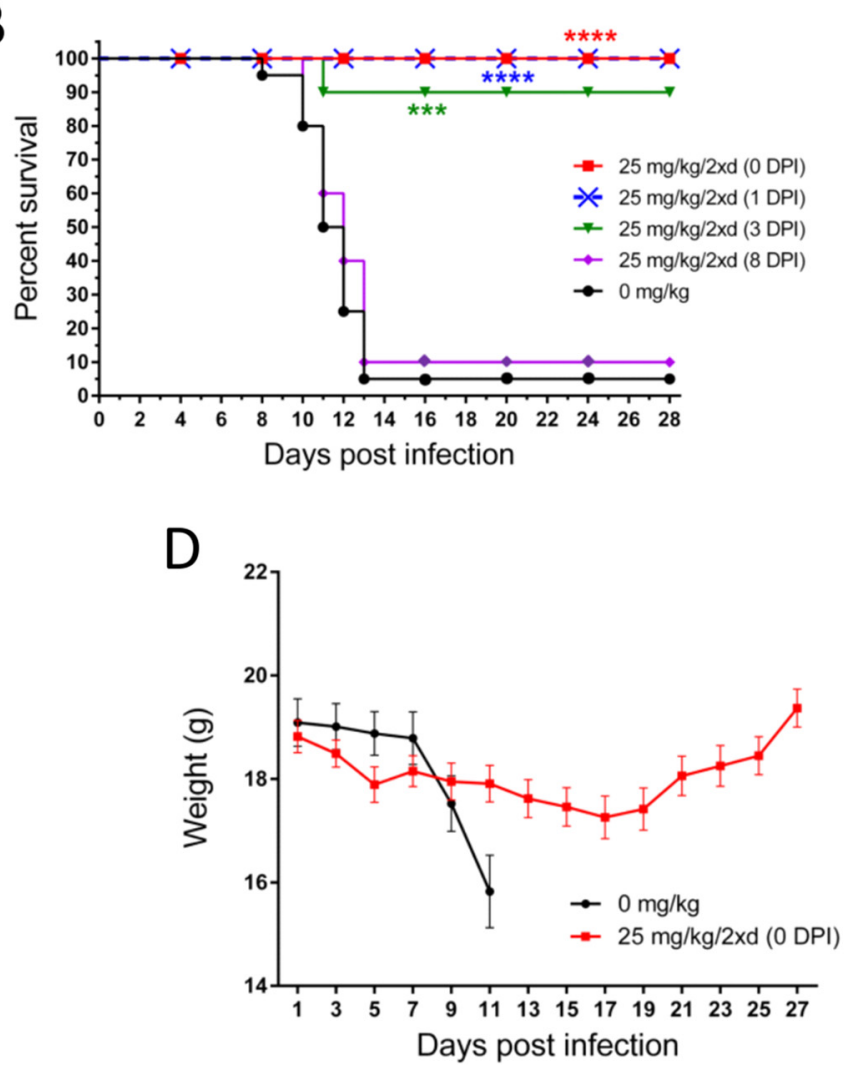

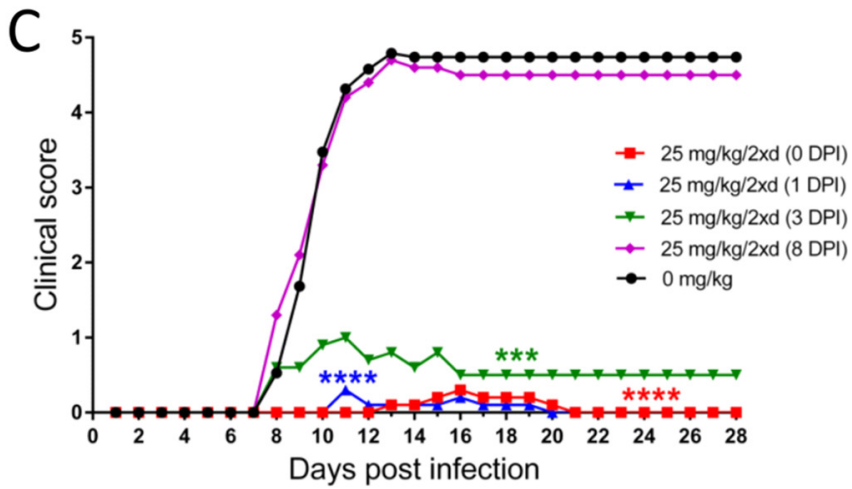

$\mathrm{E}$

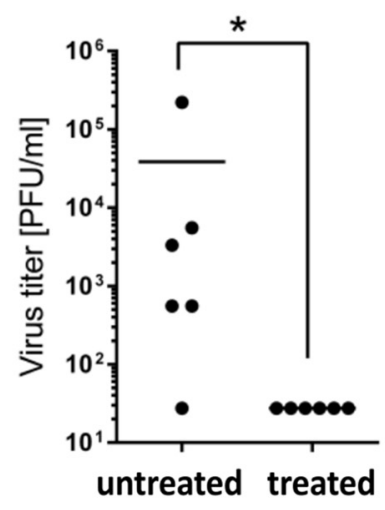

FIG 3 7-Deaza-2'-CMA is effective at treating lethal West Nile virus (WNV) infection in a mouse model. (A) The design of the in vivo antiviral experiment. (B) Groups of adult BALB/c mice were infected with a lethal dose of WNV (strain 13-104) and treated twice daily with intraperitoneal 25 mg/kg 7-deaza-2'-CMA or saline (mock treatment) at the indicated times after WNV infection. Survival rates were monitored daily for 28 days. (C) Disease signs were scored as follows: 0 , no signs; 1 , ruffled fur; 2 , slowing of activity or hunched posture; 3 , asthenia or mild paralysis; 4 , lethargy, tremor, or complete paralysis of the limbs; 5 , death. (D) Changes in body weight within a 28-day experimental period. Points indicate the mean body weight values of ten mice, and the error bars indicate the standard errors of the means. (E) Groups of adult BALB/C mice were infected with a lethal dose of WNV and treated with 7-deaza-2'-CMA or saline. On day 10 postinfection, which corresponds to advanced brain infection, the brains of mice were collected and homogenized and the viral titers determined by plaque assay. ${ }^{*}, P<0.05 ;{ }^{* *}, P<0.001 ;{ }^{* * *}, P<0.0001$.

fur and slowing activity between 13 and 20 days p.i (Fig. 3C). WNV-infected 7-deaza2'-CMA-treated mice had a slight loss of body weight (8.2\%) by 17 days p.i.; the weight began to increase again after 18 days p.i. (Fig. 3D). No viable virus was demonstrated in the brains of WNV-infected compound-treated mice 10 days p.i. (Fig. 3E). No apparent toxicity or other side effects were observed in mice treated with 7-deaza-2'-CMA ( $25 \mathrm{mg} / \mathrm{kg}$, twice a day) throughout the treatment period.

A second study was performed to determine the therapeutic effect of treatment initiated at various times after WNV infection. A delayed start of treatment $(25 \mathrm{mg} / \mathrm{kg}$, twice daily), at 1 day p.i., resulted in a $100 \%$ survival rate $(P<0.0001)$ (Fig. 3B). Nine of ten animals exhibited no significant signs of disease; in one animal, slightly ruffled fur 
was observed between 11 and 20 days p.i. (Fig. 3C). Similarly, treatment started 3 days p.i., at the time of peak of viremia, significantly protected the infected animals from disease development and mortality $(90 \%$ survival rate, $P<0.001)$ and substantially eliminated the appearance of signs of clinical infection (Fig. 3B and C). However, treatment initiated 8 days p.i. (i.e., when the first signs of disease appeared) was inefficient; in this group of animals, characteristic clinical signs of disease were observed within 7 to 12 days p.i. The infection was $90 \%$ lethal with a mean survival time of $11.5 \pm 1.29$ days (Fig. 3B and C).

\section{DISCUSSION}

WNV is a medically important emerging arbovirus able to cause serious neuroinfections in humans, against which no approved antiviral therapy is currently available. Therefore, there is an urgent medical need to develop innovative and effective smallmolecule-based antivirals to treat patients with WNV infection (14). Here, we evaluated the antiviral activity and cytotoxicity of 2'-C-methyl-, 2'-O-methyl-, 3'-O-methyl-, 3'deoxy-, and $4^{\prime}$-azido-modified nucleosides. These compounds were originally developed for the treatment of chronic hepatitis C (29-35), and some were later repurposed to suppress viral infections caused by tick- and mosquito-borne flaviviruses $(27,32,33$, 36-41).

Our in vitro antiviral screens revealed that a methyl substituent at the $C 2{ }^{\prime}$ nucleoside position is an important structural determinant to suppress the replication of WNV in cell culture. Nucleosides methylated at the $\mathrm{C2}^{\prime}$ position have also been reported to strongly inhibit TBEV (27, 36, 38), DENV $(42,43)$, ZIKV $(37,41,44,45)$, Alkhurma hemorrhagic fever virus, Kyasanur Forest disease virus, Omsk hemorrhagic fever virus, and Powassan virus (39), as well as numerous representatives of the Picornaviridae and Caliciviridae families (46-48). This indicates that 2' -C-methylated nucleosides are broadrange inhibitors of a large variety of single-stranded plus-sense RNA viruses. We observed that the anti-WNV activity of $2^{\prime}-C$-methylated nucleosides is strongly influenced by the identity of the heterocyclic nucleobase and was demonstrated to decrease in the order as follows: $2^{\prime}-C$-methyladenosine $>2^{\prime}-C$-methylcytidine $>2^{\prime}-C$ methylguanosine $>2^{\prime}$-C-methyluridine. The surprisingly low in vitro antiviral activity of $2^{\prime}$-C-methyluridine was also previously reported for TBEV and ZIKV $\left(E_{50} \mathrm{~S}\right.$ of $11.1 \pm 0.4 \mu \mathrm{M}$ and $45.45 \pm 0.64 \mu \mathrm{M}$, respectively) $(27,37)$. This phenomenon might be ascribed to rapid nucleoside degradation with cellular uridine phosphorylase, a cytoplasmic enzyme playing an important role in uridine catabolism $(49,50)$.

In contrast, 7-deaza-2'-CMA, in which a $C 2^{\prime}$-methylated riboside is bound to a 7-deaza-modified adenine, exhibited significantly increased anti-WNV efficacy and low cytotoxicity in cell lines of both neuronal (SK-N-SH) and extraneural (PS and Vero) origins. This nucleoside has been reported to have greater metabolic stability, better bioavailability, and a longer half-life in beagle dogs and rhesus monkeys than its parent compound, 2'-C-methyladenosine (33). Moreover, 7-deaza modification introduced into anti-DENV nucleoside 2 '-C-ethynyladenosine resulted in a dramatic decrease in compound cytotoxicity, as demonstrated for NIDT008 in multiple cell-based systems and in vivo (51). Interestingly, elimination of the $C 2$ ' methyl from 7-deaza-2'-CMA led to extremely high in vitro cytotoxicity of 7-deazaadenosine (tubercidin) and its derivatives sangivamycin and toyocamycin. Our anti-TBEV screens revealed that further modification of 7-deaza-2'-CMA at position 6 (e.g., 6-hydroxyamino or 6-hydrazinyl), position 7 (e.g., 7-nitro, 7-phenyl, 7-fluoro, 7-cyano, 7-ethynyl, or 7-trifluoromethyl), or positions 6 and 7 (e.g., 6-dymethylamino-7-iodo, 6-cyclopropylamino-7-iodo, or 6-morpholino-7iodo) led to a complete loss of antiviral activity (unpublished results). We can conclude that 7-deaza modification of adenosine combined with a 2'-C-methyl substituent results in higher antiviral activity, decreased toxicity, and improved pharmacokinetic profile (33); however, 7-deaza modification itself is responsible for a conspicuous increase in cytotoxicity. On the other hand, the lack of antiviral activity of $\mathrm{O}^{\prime}$ - or O3'-methylated or 3'-deoxy-modified nucleosides might be explained by the absence of $2^{\prime}$ - and $3^{\prime}$-hydroxyls positioned in the $\alpha$-face of the nucleoside scaffold, which are 
considered to be crucial for specific hydrogen-bonding interactions of the nucleoside molecule with the flaviviral polymerase active site during RNA replication $(27,29)$. Moreover, 2'-O-methylcytidine has been observed to be inefficiently phosphorylated by intracellular kinases and/or extensively deaminated/demethylated in various cell cultures (27).

The 4 '-azido moiety appears to be another important determinant of highly efficient inhibition of WNV replication in vitro, as exemplified by two cytidine derivatives: 4 '-azidocytidine and 4'-azido-aracytidine. The high anti-WNV activity of both compounds has been observed to be strongly cell type dependent and might be ascribed to differences in compound uptake or the metabolic processing of both nucleosides by individual cell lines (52). Cell-type-dependent antiviral activity of 4 '-azido-modified nucleosides was also previously reported for TBEV; the compounds were active in PS cells but their activity was completely abrogated in human neuroblasts (27). The cell-type-dependent antiviral effect can sometimes affect the results of antiviral screens; therefore, multiple clinically relevant cell lines are needed for antiviral testing (52). Similarly to 2 '-C-methyluridine, 4'-azidouridine exhibits no anti-WNV activity, probably because of low metabolic stability and rapid degradation by cellular uridine phosphorylases $(49,50)$.

Based on our finding that 7-deaza-2'-CMA is a strong inhibitor of WNV replication in cell culture, we evaluated the antiviral effect of this compound in a lethal mouse model of WNV infection. A dose of $25 \mathrm{mg} / \mathrm{kg}$ 7-deaza-2'-CMA administered intraperitoneally twice a day starting the day of WNV infection resulted in a $100 \%$ survival rate. The treated animals exhibited no clinical signs of neuroinfection, and no viral titer was determined in mouse brains. The same treatment regimen with 7-deaza-2'-CMA (25 mg/kg, twice daily, starting at the time of infection) was used to treat TBEV-infected $\mathrm{BALB} / \mathrm{c}$ mice, which had slightly lower survival rates (60\%) and worse clinical scores than WNV-infected animals (36).

The treatment initiated at the time of infection does not correlate with potential human drug use, as the therapy usually begins during the neurological phase of the disease. Therefore, we tested the therapeutic effect of treatment initiated at various times after WNV infection. Mice infected with WNV have peak viremia between 48 and $72 \mathrm{~h}$ p.i. The virus then crosses the blood-brain barrier (BBB) and establishes brain infection $(53,54)$. Therefore, treatment was started in mice before viremia (1 day p.i.), during peak viremia ( 3 days p.i.), and at the time of established brain infection ( 8 days p.i.). A delayed start of treatment $(25 \mathrm{mg} / \mathrm{kg}$, twice daily), 1 day p.i., resulted in the survival of all infected mice. Even the treatment initiated 3 days p.i. (at the time of a peak of viremia) showed a high antiviral efficacy, protecting $90 \%$ of mice from disease development and mortality. However, animals treated after 8 days p.i. (i.e., at the time of extensive brain infection) had only a slightly higher survival rate and negligibly prolonged mean survival time compared to that of mock-treated mice. The results suggest that treatment with 7-deaza-2'-CMA is highly effective, even when started 1 or 3 days p.i. (i.e., before the virus infects the brain). We do not have any data if 7-deaza-2'-CMA crosses the intact BBB, but disruption of the BBB is one of the hallmarks of flavivirus encephalitis (53), which facilitates drug delivery into the brain. However, the fact that the therapy initiated on day 8 p.i. had no or little effect in terms of protection against the lethal disease is not suprising due to the extensive brain infection and inflammation already present at this time point.

Strong in vivo antiviral activity of 7-deaza-2'-CMA has also been demonstrated in other medically important flaviviruses. This compound substantially improves disease outcome, increases survival, and reduces signs of neuroinfection and viral titers in the brains of BALB/c mice infected with TBEV (36). 7-Deaza-2'-CMA also reduces viremia in AG129 mice infected with the African strain of ZIKV (45) and is a potent inhibitor of DENV in a mouse model of dengue viremia (55). Although 7-deaza-2' -CMA has failed in human clinical tests for chronic hepatitis $C$ treatment, probably due to mitochondrial toxicity (56), this compound might still be suitable and safe for short-term therapy of acute flaviviral diseases, including WNV infections (57), and represents one of the most 
promising candidates for the treatment of flaviviral infections to date. Alternatively, 7-deaza-2'-CMA can represent a reference compound/comparator in future studies (45).

In conclusion, our results demonstrate that nucleosides with a $C 2$ ' methyl substituent are potent inhibitors of WNV replication in vitro. The leading structure of this group, 7-deaza-2'-CMA, exerted significant anti-WNV activity in a mouse model of WNV infection. This compound protected WNV-infected mice from disease signs/death, even if the treatment was initiated 3 days p.i. Some other substituents were introduced into the $C 2$ ' nucleoside position previously, particularly $2^{\prime}$-C-ethynyl in anti-DENV nucleoside NITD008 $(51,57,58)$ or $2^{\prime}$-fluoro-2'-C-methyl in the case of sofosbuvir, which inhibits ZIKV in vitro and in rodent models of ZIKV infection (59). A variety of promising modifications at $C 2^{\prime}$ indicate that this nucleoside position provides a large chemical space for possible changes/substitutions to develop efficient nucleoside inhibitors of flaviviral replication. Another important structural modification for efficient WNV inhibition is $4^{\prime}$-azido substitution of cytidine-based nucleosides. Although these compounds have been tested only in vitro, 4-azido-aracytidine had a nanomolar anti-WNV effect and a good cytotoxicity profile. This molecule will be tested in vivo in our future studies. Our data strongly suggest that nucleoside analogs represent a rich source of promising inhibitors for the further design and development of innovative and effective drugs active against important human pathogens, including flaviviruses.

\section{MATERIALS AND METHODS}

Ethics statement. This study was carried out in strict accordance with Czech law and guidelines for the use of experimental animals and protection of animals against cruelty (Animal Welfare Act 246/1992 Coll.). All procedures were reviewed by the local ethics committee and approved by the Ministry of Agriculture of the Czech Republic (permit no. 22006/2016-MZE-17214).

Cell cultures, virus strains, and antiviral compounds. PS cells (60), a cell line widely used for the isolation and multiplication of arthropod-borne flaviviruses, were cultured at $37^{\circ} \mathrm{C}$ in L-15 (Leibovitz) medium containing $1 \mathrm{mM}$ L-glutamine, 4\% fetal bovine serum, and 1\% penicillin and streptomycin (Sigma-Aldrich, Prague, Czech Republic). Epithelial kidney (Vero) cells from Cercopithecus aethiops were cultured in minimum essential medium (MEM) containing 10\% fetal bovine serum, 5\% L-glutamine, and $1 \%$ penicillin and streptomycin (Sigma-Aldrich, Prague, Czech Republic) at $37^{\circ} \mathrm{C}$ in a $5 \% \mathrm{CO}_{2}$ atmosphere. Human neuroblastoma cells (SK-N-SH) were cultured at $37^{\circ} \mathrm{C}$ in $5 \% \mathrm{CO}_{2}$ in Iscove's modified Dulbecco's medium (IMDM) with 10\% fetal bovine serum and a 1\% mixture of antibiotics. Two distinct low-passage WNV strains were used to evaluate the anti-WNV activity of the tested compounds. Eg-101, a member of genomic lineage 1, was originally isolated from human serum in Egypt in 1951 (61). WNV strain 13-104, a representative of genomic lineage 2 , was isolated from the Culex modestus mosquito in the Czech Republic in 2013 (62).

2'-C-Methyl-, 2'-O-methyl-, and 3'-O-methyl-substituted nucleoside analogs and 3'-deoxynucleosides were purchased from Carbosynth (Compton, UK). 4'-Azido-modified nucleosides and BCX-4430 were obtained from MedchemExpress (Stockholm, Sweden). Tubercidin, toyocamycin, and sangivamycin were purchased from Sigma-Aldrich (Prague, Czech Republic). 7-Deaza-2'-CMA was synthesized at the Institute of Organic Chemistry and Biochemistry in Prague. Nucleoside analogs were diluted in $100 \%$ dimethyl sulfoxide (DMSO) to $10 \mathrm{mM}$ stock solutions.

Antiviral assays. To perform the viral titer reduction assay, PS cells were seeded in 96-well plates (approximately $3 \times 10^{4}$ cells per well) and incubated for $24 \mathrm{~h}$ at $37^{\circ} \mathrm{C}$ to form a confluent monolayer. The medium was then aspirated from the wells and replaced with $200 \mu$ l of fresh medium containing $50 \mu \mathrm{M}$ of the test compounds and the appropriate virus strain at a multiplicity of infection (MOI) of 0.1 . Virus-infected cells treated with BCX-4430 (63) and DMSO (mock-treated cells) were used as positive and negative controls, respectively. The culture medium was collected 3 days p.i. and viral titers (expressed as PFU/ml) were determined from the collected culture medium by plaque assays $(38,64)$.

As the antiviral effect of many compounds is cell type dependent, we further tested the anti-WNV activity of nucleoside analogs in Vero cells in cytopathic effect (CPE) inhibition assays. Vero cells were seeded in 96-well plates, incubated to form a confluent monolayer, and treated with virus and tested compounds as described for the viral titer inhibition assay. The cells were examined microscopically for virus-induced CPE. Three days postinfection, the supernatant medium was aspirated from the cells, and the cell culture was stained with naphtalene black. The rate of CPE was expressed in terms of cell viability as the absorbance at $540 \mathrm{~nm}$ by compound-treated cells relative to the absorbance by DMSO-treated cells.

The dose-dependent antiviral activities of selected WNV inhibitors were assessed as follows. PS cells were seeded in 96-well plates (approximately $3 \times 10^{4}$ cells per well) and incubated at $37^{\circ} \mathrm{C}$ to form a confluent monolayer. After a $24-\mathrm{h}$ incubation, the medium was aspirated from the wells and replaced with a fresh medium containing the tested compounds over the concentration range of 0 to $50 \mu \mathrm{M}$ and appropriate WNV strain (MOI 0.1). The culture medium was collected continuously 2, 3, and 5 days p.i. The viral titers (expressed as PFU/ml) were determined from the collected supernatant media by a plaque 
titration assay and used to construct dose-dependent and inhibition curves. The viral titers obtained 3 days p.i. were used for calculation of the $50 \%$ effective concentrations $\left(\mathrm{EC}_{50}\right.$; the concentration of compounds required to inhibit the viral titer by $50 \%$ compared to the control value). The dosedependent study was carried out also with human neuroblastoma cells (SK-N-SH) at the concentration range from 0 to $50 \mu \mathrm{M}$.

Immunofluorescence staining. The results obtained from antiviral assays were confirmed by a cell-based flavivirus immunostaining assay, a method based on determining the compound-induced inhibition of viral surface antigen (E protein) expression (38). Briefly, PS cells seeded on 96-well plates were treated with the test compound $(50 \mu \mathrm{M})$ and infected with WNV strains Eg-101 or 13-104 at an MOI of 0.1 . After a 3-day incubation at $37^{\circ} \mathrm{C}$, the cell monolayers were fixed with cold acetone-methanol (1:1), blocked with $10 \%$ fetal bovine serum, and incubated with a mouse monoclonal antibody that specifically recognizes the flavivirus group surface antigen (1:250; Sigma-Aldrich, Prague, Czech Republic). After extensive washing, the cells were labeled with an anti-mouse goat secondary antibody conjugated with fluorescein isothiocyanate (FITC; 1:500) and counterstained with DAPI (4',6-diamidino-2-phenylindole; $1 \mu \mathrm{g} / \mathrm{ml}$ ) to visualize the cell nuclei. The fluorescence signal was recorded with an Olympus IX71 epifluorescence microscope.

Cytotoxicity assay. PS, Vero, or SK-N-SH cells grown in 96-well plates for $24 \mathrm{~h}$ to form a confluent monolayer were treated with test compounds over the concentration range of 0 -to $50 \mu \mathrm{M}$. Three days posttreatment, the cell culture medium was collected, and the potential cytotoxicity of test nucleosides was determined in terms of cell viability using a Cell Counting kit-8 (Dojindo Molecular Technologies, Munich, Germany) according to the manufacturer's instructions. The compound concentration that reduced cell viability by $50 \%$ was considered the $50 \%$ cytotoxic concentration $\left(\mathrm{CC}_{50}\right)$.

Mouse infections. To evaluate the anti-WNV effect of 7-deaza-2'-CMA in vivo, five groups of 6-week-old female BALB/c mice (purchased from AnLab, Prague, Czech Republic) were subcutaneously injected with WNV strain 13-104 (1,000 PFU/mouse) and treated intraperitoneally with $200 \mu \mathrm{l}$ of 7-deaza-2'-CMA (25 mg/kg twice a day at 8-h intervals) as follows: group $1(n=10)$, treatment initiated immediately after infection ( 0 days p.i.); group $2(n=10)$, treatment initiated 1 day p.i.; group $3(n=10)$, treatment initiated 3 days p.i.; group $4(n=10)$, treatment initiated 8 days p.i. (when the first clinical signs appeared); and group $5(n=10)$, control animals, treated with vehicle only. 7-Deaza-2'-CMA was freshly solubilized in sterile saline buffer before each injection and administered to the animals for 19 (group 1), 18 (group 2), 16 (group 3), and 11 (group 4) days. The clinical scores, body weights, and survival rates of WNV-infected mice were monitored daily over 28 days. Illness signs were evaluated as follows: 0 for no symptoms; 1 for ruffled fur; 2 for slowing of activity or hunched posture; 3 for asthenia or mild paralysis; 4 for lethargic, tremor, or complete paralysis of the limbs; 5 for death. All mice exhibiting disease consistent with clinical score 4 were terminated humanely (cervical dislocation) immediately upon detection.

For determination of the WNV titer in mouse brains, a group of 6-week-old BALB/c mice were infected subcutaneously with 1,000 PFU of WNV and immediately treated with 7-deaza-2'-CMA twice daily at a concentration of $25 \mathrm{mg} / \mathrm{kg}$. Ten days postinfection, when the clinical symptoms of WNV disease were clearly observable in mice treated with vehicle only, the animals were sacrificed and the brains were collected, weighed, homogenized using Precellys 24 (Bertin Technologies), and prepared as 20\% (wt/vol) suspensions in saline. Each homogenate was centrifuged at 5,000 $\times g$, and the supernatant medium was used to determine virus titer by plaque assay.

Statistical analysis. Data are expressed as means \pm standard deviation $(\mathrm{SDs})$, and the significance of differences between groups was evaluated by the Mann-Whitney $U$ test or analysis of variance (ANOVA). Survival rates were analyzed using the log rank Mantel-Cox test. All tests were performed using GraphPad Prism 7.04 (GraphPad Software, Inc., USA). A $P$ value of $<0.05$ was considered significant.

\section{ACKNOWLEDGMENT}

This study was supported by a grant from the Czech Science Foundation (grant 16-20054S). The funder had no role in the study design, data collection and analysis, decision to publish, or preparation of the manuscript.

\section{REFERENCES}

1. Baier A. 2011. Flaviviral infections and potential targets for antiviral therapy, p 89-104. In Ruzek D (ed), Flavivirus encephalitis. InTech, Rijeka, Croatia.

2. Beasley DWC, Davis CT, Whiteman M, Granwehr B, Kinney RM, Barrett ADT. 2004. Molecular determinants of virulence of West Nile virus in North America. Arch Virol 18:35-41.

3. Chambers TJ, Hahn CS, Galler R, Rice CM. 1990. Flavivirus genome organization, expression, and replication. Annu Rev Microbiol 44: 649-688. https://doi.org/10.1146/annurev.mi.44.100190.003245.

4. Khromykh AA, Sedlak PL, Guyatt KJ, Hall RA, Westaway EG. 1999. Efficient trans-complementation of the flavivirus Kunjin NS5 protein but not of the NS1 protein requires its coexpression with other components of the viral replicase. J Virol 73:10272-10280.

5. Lin RJ, Chang BL, Yu HP, Liao CL, Lin YL. 2006. Blocking of interferon- induced Jak-Stat signaling by Japanese encephalitis virus NS5 through a protein tyrosine phosphatase-mediated mechanism. J Virol 80: 5908-5918. https://doi.org/10.1128/JVI.02714-05.

6. Liu WJ, Wang XJ, Mokhonov VV, Shi PY, Randall R, Khromykh AA. 2005. Inhibition of interferon signaling by the New York 99 strain and Kunjin subtype of West Nile virus involves blockage of STAT1 and STAT2 activation by nonstructural proteins. J Virol 79:1934-1942. https://doi .org/10.1128/JVI.79.3.1934-1942.2005.

7. Hubalek Z. 2000. European experience with the West Nile virus ecology and epidemiology: could it be relevant for the new world? Viral Immunol 13:415-426.

8. Smithburn K, Hughes T, Burke A, Paul J. 1940. A neurotropic virus isolated from the blood of a native of Uganda. Am J Trop Med Hyg 20:471-492. https://doi.org/10.4269/ajtmh.1940.s1-20.471. 
9. Dauphin G, Zientara S, Zeller H, Murgue B. 2004. West Nile: worldwide current situation in animals and humans. Comp Immunol Microbiol Infect Dis 27:343-355. https://doi.org/10.1016/j.cimid.2004.03.009.

10. Deardorff E, Estrada-Franco J, Brault AC, Navarro-Lopez R, CampomanesCortes A, Paz-Ramirez P, Solis-Hernandez M, Ramey WN, Davis CT, Beasley DW, Tesh RB, Barrett AD, Weaver SC. 2006. Introductions of West Nile virus strains to Mexico. Emerg Infect Dis 12:314-318. https://doi .org/10.3201/eid1202.050871.

11. Komar N, Clark GG. 2006. West Nile virus activity in Latin America and the Caribbean. Rev Panam Salud Publica 19:112-117.

12. Mostashari F, Bunning ML, Kitsutani PT, Singer DA, Nash D, Cooper MJ, Katz N, Liljebjelke KA, Biggerstaff BJ, Fine AD, Layton MC, Mullin SM, Johnson AJ, Martin DA, Hayes EB, Campbell GL. 2001. Epidemic West Nile encephalitis, New York, 1999: results of a household-based seroepidemiological survey. Lancet 358:261-264. https://doi.org/10.1016/S0140 $-6736(01) 05480-0$

13. Tsai TF, Popovici F, Cernescu C, Campbell GL, Nedelcu NI. 1998. West Nile encephalitis epidemic in southeastern Romania. Lancet 352:767-771.

14. Lim SM, Koraka P, Osterhaus ADME, Martina BEE. 2011. West Nile virus: immunity and pathogenesis. Viruses 3:811-828. https://doi.org/10.3390/ v3060811.

15. Chowers MY, Lang R, Nassar F, Ben-David D, Giladi M, Rubinshtein E, Itzhaki A, Mishal J, Siegman-Igra Y, Kitzes R, Pick N, Landau Z, Wolf D, Bin $\mathrm{H}$, Mendelson E, Pitlik SD, Weinberger M. 2001. Clinical characteristics of the West Nile fever outbreak, Israel, 2000. Emerg Infect Dis 7:675-678. https://doi.org/10.3201/eid0704.010414.

16. Nash D, Mostashari F, Fine A, Miller J, O'Leary D, Murray K, Huang A, Rosenberg A, Greenberg A, Sherman M, Wong S, Layton M, Campbell GL, Roehrig JT, Gubler DJ, Shieh WJ, Zaki S, Smith P. 2001. The outbreak of West Nile virus infection in the New York City area in 1999. N Engl J Med 344:1807-1814. https://doi.org/10.1056/NEJM200106143442401.

17. Samuel MA, Diamond MS. 2006. Pathogenesis of West Nile virus infection: a balance between virulence, innate and adaptive immunity, and viral evasion. J Virol 80:9349-9360. https://doi.org/10.1128/ JVI.01122-06.

18. De Clercq E. 2011. A 40-year journey in search of selective antiviral chemotherapy. Annu Rev Pharmacol Toxicol 51:1-24. https://doi.org/10 .1146/annurev-pharmtox-010510-100228.

19. De Clercq E. 2004. Antivirals and antiviral strategies. Nat Rev Microbiol 2:704-720. https://doi.org/10.1038/nrmicro975.

20. De Clercq E. 2008. Emerging antiviral drugs. Expert Opin Emerg Drugs 13:393-416. https://doi.org/10.1517/14728214.13.3.393.

21. De Clercq E, Neyts J. 2009. Antiviral agents acting as DNA or RNA chain terminators. Handb Exp Pharmacol 189:53-84. https://doi.org/10.1007/ 978-3-540-79086-0_3.

22. Benhamou Y, Tubiana R, Thibault V. 2003. Tenofovir disoproxil fumarate in patients with HIV and lamivudine-resistant hepatitis B virus. N Engl J Med 348:177-178. https://doi.org/10.1056/NEJM200301093480218.

23. De Clercq E, Holý A. 2005. Acyclic nucleoside phosphonates: A key class of antiviral drugs. Nat Rev Drug Discov 4:928-940. https://doi.org/10 1038/nrd1877.

24. Huang YS, Chang SY, Sheng WH, Sun HY, Lee KY, Chuang YC, Su YC, Liu WC, Hung CC, Chang SC. 2016. Virological response to tenofovir disoproxil fumarate in HIV-positive patients with lamivudine-resistant hepatitis $B$ virus coinfection in an area hyperendemic for hepatitis B virus infection. PLoS One 11:e0169228. https://doi.org/10.1371/journal.pone .0169228 .

25. Ray AS, Fordyce MW, Hitchcock MJM. 2016. Tenofovir alafenamide: a novel prodrug of tenofovir for the treatment of human immunodeficiency virus. Antiviral Res 125:63-70. https://doi.org/10.1016/j.antiviral .2015.11.009.

26. Stedman C. 2014. Sofosbuvir, a NS5B polymerase inhibitor in the treatment of hepatitis C: a review of its clinical potential. Therap Adv Gastroenterol 7:131-140. https://doi.org/10.1177/1756283X13515825.

27. Eyer L, Šmídková M, Nencka R, Neča J, Kastl T, Palus M, De Clercq E, Růžek D. 2016. Structure-activity relationships of nucleoside analogues for inhibition of tick-borne encephalitis virus. Antiviral Res 133:119-129. https://doi.org/10.1016/j.antiviral.2016.07.018.

28. Kumar M, O'Connell M, Namekar M, Nerurkar VR. 2014. Infection with non-lethal West Nile virus Eg101 strain induces immunity that protects mice against the lethal West Nile virus NY99 strain. Viruses 6:2328-2339. https://doi.org/10.3390/v6062328.

29. Eldrup $A B$, Allerson $C R$, Bennett $C F$, Bera $S$, Bhat $B$, Bhat $N$, Bosserman MR, Brooks J, Burlein C, Carroll SS, Cook PD, Getty KL, MacCoss M,
McMasters DR, Olsen DB, Prakash TP, Prhavc M, Song QL, Tomassini JE, Xia J. 2004. Structure-activity relationship of purine ribonucleosides for inhibition of hepatitis C virus RNA-dependent RNA polymerase. J Med Chem 47:2283-2295. https://doi.org/10.1021/jm030424e.

30. Klumpp K, Leveque V, Le PS, Ma H, Jiang WR, Kang HS, Granycome C, Singer M, Laxton C, Hang JQ, Sarma K, Smith DB, Heindl D, Hobbs CJ, Merrett JH, Symons J, Cammack N, Martin JA, Devos R, Najera I. 2006. The novel nucleoside analog R1479 (4'-azidocytidine) is a potent inhibitor of NS5B-dependent RNA synthesis and hepatitis C virus replication in cell culture. J Biol Chem 281:3793-3799. https://doi.org/10.1074/jbc .M510195200.

31. Klumpp K, Kalayanov G, Ma H, Le Pogam S, Leveque V, Jiang WR, Inocencio N, De Witte A, Rajyaguru S, Tai E, Chanda S, Irwin MR, Sund C, Winqist A, Maltseva T, Eriksson S, Usova E, Smith M, Alker A, Najera I, Cammack N, Martin JA, Johansson NG, Smith DB. 2008. 2'-Deoxy-4'-azido nucleoside analogs are highly potent inhibitors of hepatitis $C$ virus replication despite the lack of 2'-alpha-hydroxyl groups. J Biol Chem 283:2167-2175. https://doi.org/10.1074/jbc.M708929200.

32. Migliaccio G, Tomassini JE, Carroll SS, Tomei L, Altamura S, Bhat B, Bartholomew L, Bosserman MR, Ceccacci A, Colwell LF, Cortese R, De Francesco R, Eldrup AB, Getty KL, Hou XS, LaFemina RL, Ludmerer SW, MacCoss M, McMasters DR, Stahlhut MW, Olsen DB, Hazuda DJ, Flores OA. 2003. Characterization of resistance to non-obligate chainterminating ribonucleoside analogs that inhibit hepatitis $C$ virus replication in vitro. J Biol Chem 278:49164-49170. https://doi.org/10.1074/ jbc.M305041200.

33. Olsen DB, Eldrup AB, Bartholomew L, Bhat B, Bosserman MR, Ceccacci $A$, Colwell LF, Fay JF, Flores OA, Getty KL, Grobler JA, LaFemina RL, Markel EJ, Migliaccio G, Prhavc M, Stahlhut MW, Tomassini JE, MacCoss M, Hazuda DJ, Carroll SS. 2004. A 7-deaza-adenosine analog is a potent and selective inhibitor of hepatitis $C$ virus replication with excellent pharmacokinetic properties. Antimicrob Agents Chemother 48:3944-3953. https://doi.org/10.1128/AAC.48.10.3944-3953.2004.

34. Smith DB, Kalayanov G, Sund C, Winqvist A, Pinho P, Maltseva T, Morisson V, Leveque V, Rajyaguru S, Le Pogam S, Najera I, Benkestock K, Zhou XX, Maag H, Cammack N, Martin JA, Swallow S, Johansson NG, Klumpp K, Smith M. 2009. The design, synthesis, and antiviral activity of 4'azidocytidine analogues against hepatitis $C$ virus replication: the discovery of 4'-azidoarabinocytidine. J Med Chem 52:219-223. https://doi.org/ 10.1021/jm800981y.

35. Sofia MJ, Chang W, Furman PA, Mosley RT, Ross BS. 2012. Nucleoside, nucleotide, and non-nucleoside inhibitors of hepatitis C virus NS5B RNA-dependent RNA-polymerase. J Med Chem 55:2481-2531. https:// doi.org/10.1021/jm201384j.

36. Eyer L, Kondo $H$, Zouharova D, Hirano M, Valdés JJ, Muto M, Kastl T, Kobayashi S, Haviernik J, Igarashi M, Kariwa H, Vaculovicova M, Cerny J, Kizek R, Kröger A, Lienenklaus S, Dejmek M, Nencka R, Palus M, Salat J, De Clercq E, Yoshii K, Ruzek D. 2017. Escape of tick-borne flavivirus from 2 '-C-methylated nucleoside antivirals is mediated by a single conservative mutation in NS5 that has a dramatic effect on viral fitness. J Virol 91:e01028-17. https://doi.org/10.1128/JVI.01028-17.

37. Eyer L, Nencka R, Huvarová I, Palus M, Joao Alves M, Gould EA, De Clercq E, Růžek D. 2016. Nucleoside inhibitors of Zika virus. J Infect Dis 214: 707-711. https://doi.org/10.1093/infdis/jiw226.

38. Eyer L, Valdés JJ, Gil VA, Nencka R, Hřebabecký H, Šála M, Salát J, Černý J, Palus M, De Clercq E, Růžek D. 2015. Nucleoside inhibitors of tickborne encephalitis virus. Antimicrob Agents Chemother 59:5483-5493. https://doi.org/10.1128/AAC.00807-15.

39. Flint M, McMullan LK, Dodd KA, Dodd KA, Bird BH, Khristova ML, Nichol ST, Spiropoulou CF. 2014. Inhibitors of the tick-borne, hemorrhagic fever-associated flaviviruses. Antimicrob Agents Chemother 58: 3206-3216. https://doi.org/10.1128/AAC.02393-14.

40. Julander JG, Jha AK, Choi JA, Jung KH, Smee DF, Morrey JD, Chu CK. 2010. Efficacy of 2'-C-methylcytidine against yellow fever virus in cell culture and in a hamster model. Antiviral Res 86:261-267. https://doi .org/10.1016/j.antiviral.2010.03.004.

41. Lanko K, Eggermont K, Patel A, Kaptein S, Delang L, Verfaillie CM, Neyts J. 2017. Replication of the Zika virus in different iPSC-derived neuronal cells and implications to assess efficacy of antivirals. Antiviral Res 145: 82-86. https://doi.org/10.1016/j.antiviral.2017.07.010.

42. Lee JC, Tseng CK, Wu YH, Kaushik-Basu N, Lin CK, Chen WC, Wu HN. 2015. Characterization of the activity of 2 -C-methylcytidine against dengue virus replication. Antiviral Res 116:1-9. https://doi.org/10.1016/ j.antiviral.2015.01.002. 
43. Mateo R, Nagamine CM, Kirkegaard K. 2015. Suppression of drug resistance in dengue virus. mBio 6:e01960-15. https://doi.org/10.1128/mBio .01960-15.

44. Hercik K, Brynda J, Nencka R, Boura E. 2017. Structural basis of Zika virus methyltransferase inhibition by sinefungin. Arch Virol 162:2091-2096. https://doi.org/10.1007/s00705-017-3345-x.

45. Zmurko J, Marques RE, Schols D, Verbeken E, Kaptein SJF, Neyts J. 2016. The viral polymerase inhibitor 7-deaza-2'-C-methyladenosine is a potent inhibitor of in vitro Zika virus replication and delays disease progression in a robust mouse infection model. PLoS Negl Trop Dis 10:e0004695. https://doi.org/10.1371/journal.pntd.0004695.

46. Lefebvre DJ, De Vleeschauwer AR, Goris N, Kollanur D, Billiet A, Murao L, Neyts J, De Clercq K. 2014. Proof of concept for the inhibition of foot-and-mouth disease virus replication by the anti-viral drug 2'-Cmethylcytidine in severe combined immunodeficient mice. Transbound Emerg Dis 61:E89-E91. https://doi.org/10.1111/tbed.12069.

47. Rocha-Pereira J, Jochmans D, Dallmeier K, Leyssen P, Cunha R, Costa I, Nascimento MS, Neyts J. 2012. Inhibition of norovirus replication by the nucleoside analogue 2'-C-methylcytidine. Biochem Bioph Res Commun 427:796-800. https://doi.org/10.1016/j.bbrc.2012.10.003.

48. Rocha-Pereira J, Jochmans D, Debing Y, Verbeken E, Nascimento MSJ, Neyts J. 2013. The viral polymerase inhibitor 2'-C-methylcytidine inhibits Norwalk virus replication and protects against norovirus-induced diarrhea and mortality in a mouse model. J Virol 87:11798-11805. https:// doi.org/10.1128/JVI.02064-13.

49. Balestri F, Barsotti C, Lutzemberger L, Camici M, Ipata PL. 2007. Key role of uridine kinase and uridine phosphorylase in the homeostatic regulation of purine and pyrimidine salvage in brain. Neurochem Int 51: 517-523. https://doi.org/10.1016/j.neuint.2007.06.007.

50. Lashkov AA, Shchekotikhin AA, Shtil AA, Sotnichenko SE, Mikhailov AM. 2016. Modified 5-fluorouracil: uridine phosphorylase inhibitor. Crystallogr Rep 61:826-829. https://doi.org/10.1134/S1063774516050138.

51. Yin Z, Chen YL, Schul W, Wang QY, Gu F, Duraiswamy J, Kondreddi RR, Niyomrattanakit P, Lakshminarayana SB, Goh A, Xu HY, Liu W, Liu B, Lim JY, Ng CY, Qing M, Lim CC, Yip A, Wang G, Chan WL, Tan HP, Lin K, Zhang B, Zou G, Bernard KA, Garrett C, Beltz K, Dong M, Weaver M, He H, Pichota A, Dartois V, Keller TH, Shi PY. 2009. An adenosine nucleoside inhibitor of dengue virus. Proc Natl Acad Sci U S A 106:20435-20439. https://doi.org/10.1073/pnas.0907010106.

52. Eyer L, Nencka R, de Clercq E, Seley-Radtke K, Růžek D. 2018. Nucleoside analogs as a rich source of antiviral agents active against arthropodborne flaviviruses. Antivir Chem Chemother 26:2040206618761299. https://doi.org/10.1177/2040206618761299.

53. Roe K, Kumar M, Lum S, Orillo B, Nerurkar VR, Verma S. 2012. West Nile virus-induced disruption of the blood-brain barrier in mice is characterized by the degradation of the junctional complex proteins and increase in multiple matrix metalloproteinases. J Gen Virol 93:1193-1203. https:// doi.org/10.1099/vir.0.040899-0.

54. Styer LM, Lim PY, Louie KL, Albright RG, Kramer LD, Bernard KA. 2011. Mosquito saliva causes enhancement of West Nile virus infection in mice. J Virol 85:1517-1527. https://doi.org/10.1128/JVI.01112-10.

55. Schul W, Chen YL, Yin Z, Keller T, Shi PY. 2010. An adenosine nucleoside inhibitor of dengue virus. Antiviral Res 86:A24-A25. https://doi.org/10 .1016/j.antiviral.2010.02.347.

56. Arnold JJ, Sharma SD, Feng JY, Ray AS, Smidansky ED, Kireeva ML, Cho A, Perry J, Vela JE, Park Y, Xu Y, Tian Y, Babusis D, Barauskus O, Peterson BR, Gnatt A, Kashlev M, Zhong W, Cameron CE. 2012. Sensitivity of mitochondrial transcription and resistance of RNA polymerase II dependent nuclear transcription to antiviral ribonucleosides. PLoS Pathog 8:e1003030. https://doi.org/10.1371/journal.ppat.1003030.

57. Chen YL, Yin Z, Lakshminarayana SB, Qing M, Schul W, Duraiswamy J, Kondreddi RR, Goh A, Xu HY, Yip A, Liu B, Weaver M, Dartois V, Keller TH, Shi PY. 2010. Inhibition of dengue virus by an ester prodrug of an adenosine analog. Antimicrob Agents Chemother 54:3255-3261. https:// doi.org/10.1128/AAC.00397-10.

58. Chen YL, Yin Z, Duraiswamy J, Schul W, Lim CC, Liu B, Xu HY, Qing M, Yip A, Wang G, Chan WL, Tan HP, Lo M, Liung S, Kondreddi RR, Rao R, Gu H, He H, Keller TH, Shi PY. 2010. Inhibition of dengue virus RNA synthesis by an adenosine nucleoside. Antimicrob Agents Chemother 54: 2932-2939. https://doi.org/10.1128/AAC.00140-10.

59. Ferreira AC, Zaverucha-do-Valle C, Reis PA, Barbosa-Lima G, Vieira YR, Mattos M, Silva PP, Sacramento C, de Castro Faria Neto HC, Campanati L, Tanuri A, Brüning K, Bozza FA, Bozza PT, Souza TML. 2017. Sofosbuvir protects Zika vrius-infected mice from mortality, preventing short- and long-term sequelae. Sci Rep 7:9409. https://doi.org/10.1038/s41598-017 -09797-8.

60. Kozuch O, Mayer V. 1975. Pig kidney epithelial (PS) cells: a perfect tool for study of flaviviruses and some other arboviruses. Acta Virol 19:498.

61. Melnick JL, Paul JR, Riordan JT, Barnett VH, Goldblum N, Zabin E. 1951. Isolation from human sera in Egypt of a virus apparently identical to West Nile virus. Proc Soc Exp Biol Med 77:661-665.

62. Rudolf I, Bakonyi T, Sebesta O, Mendel J, Peško J, Betášová L, Blažejová H, Venclíková K, Straková P, Nowotny N, Hubálek Z. 2014. West Nile virus lineage 2 isolated from Culex modestus mosquitoes in the Czech Republic, 2013: expansion of the European WNV endemic area to the North? Euro Surveill 19:2-5. https://www.eurosurveillance.org/content/10.2807/ 1560-7917.ES2014.19.31.20867.

63. Eyer L, Zouharová D, Širmarová J, Fojtíková M, Štefánik $M$, Haviernik J, Nencka R, de Clercq E, Růžek D. 2017. Antiviral activity of the adenosine analogue BCX4430 against West Nile virus and tick-borne flaviviruses. Antiviral Res 142:63-67. https://doi.org/10.1016/j.antiviral.2017.03.012.

64. De Madrid AT, Porterfield JS. 1969. A simple micro-culture method for study of group B arboviruses. Bull World Health Organ 40:113-121. 